\title{
"A Study on the Challenges of Woman Entreprenuers in Dakshina Kannada District"
}

\author{
Girish Shanbhogue ${ }^{1}$, Swathi Bhat ${ }^{2}$, Ayisha Khathoon ${ }^{3}$, Akshatha $^{4}$, Swathi $^{5}$ \\ ${ }^{1}$ Associate Professor, Alva's PG Department of Commerce \\ ${ }^{2}$ Lecturer Alva's B.Com Department \\ ${ }^{3} 2^{\text {nd }}$ year Student ,Alva's PG Department of Commerce \\ ${ }^{4} 2^{\text {nd }}$ year Student, Alva's $P G$ Department of Commerce \\ ${ }^{5} 2^{\text {nd }}$ year Student, Alva's PG Department of Commerce
}

\begin{abstract}
In today's world, women entrepreneurs are playing very vital role and they have become important part of the global business environment and it's really important for the sustained economic development and social progress. In India, though women are playing key role in the society, but still their entrepreneurial ability has not been properly tapped due to the lower status of women in the society. The paper has made an attempt to identify how the women's are executing their roles in the society The main purpose of this is to find out the status of women entrepreneurs in India. This paper includes rationale grounds behind the women entrepreneurship. It has made an effort to study the situations and challenges faced by them. On the basis of the study some suggestions are given to encourage spirit of women entrepreneurship to become a successful entrepreneur.
\end{abstract}

\section{Introduction}

Women entrepreneurs may be define as the women or group of women who commence and operate a business venture. Like a male entrepreneurs a women entrepreneur has many functions. They should explore the prospects of starting new enterprise; undertake risks, introduction of new innovations, coordination, administration and control of business and providing effective leadership in all aspects of business. Government of India has described women entrepreneurs as an enterprise owned and controlled by women having at least financial interest of $51 \%$ of the capital and giving at least $51 \%$ of employment generated in the organization to women.

Women entrepreneurs are highly increasing in the economies of almost all countries. The hidden business potentials of women have been increasing with the growing sensitivity to the role and economic status in the society. The knowledge, Skill and compliance in business are the core reason for women to come forward into business ventures. Women entrepreneurs engage in business due to push and pull factors which give confidence to women to have an self-sufficient occupation and stands on their foots. Logic towards independent decision-making on their life and career is the motivational factor behind this insists on 'Women Entrepreneurs' is a person who accept challenging role to meet her personal desires and turn out to be economically independent. A strong desire to do enormous positive is an integral quality of entrepreneurial women, who is competent of contributing values in both family and social life. With the introduction of media, women are conscious of their own qualities, rights and also the work situation. The glass ceilings are shattered and women are found indulged in every line of business from aachaar to telecommunication

\section{Objectives:}

- To understand the family support to establish enterprises to women entrepreneurs.

- To understand the strategies used by entrepreneurs.

- To examine the obstacles in establishing enterprises.

- To identify the opportunities for women entrepreneurs

Research Design

- Primary Data: The questionnaire was prepared and opinions of 30 respondents were collected.

- Secondary Data: Information collected through various journals, research articles and through the internet.

Limitations of the study:

- The collected information subjective as the study also includes secondary information.

- Time was the limiting factor in depth analysis was not possible.

- Respondents has given the information to the best of their Knowledge to a certain extent there could be variations as to the accuracy of facts or data 


\section{Functions of Women Entrepreneurs:}

As an entrepreneur, a woman entrepreneur has also to perform all the functions involved in establishing an enterprise. These include idea generation and screening, determination of objectives, project preparation, product analysis, and determination of forms of business organization, completion of promotional formalities, raising funds, procuring men, machine and materials, and operation of business.

\section{Schemes for Women Entrepreneurs}

1. Seed Capital Scheme

2. National Equity Fund

3. Prime Minister's Employment Guarantee Scheme

4. Single Window Scheme.

5. Bank Schemes for Women Entrepreneur

6. Mahila Artik Vikas Mahamandal

Advantages of being a female entrepreneur:

$>$ Women entrepreneurs experience higher well-being: Female entrepreneurs experience a higher level of "purpose well-being" than male entrepreneurs and other workers. Purpose well-being means learning or doing something interesting, liking what you do, and using your strengths to do what you do best.

$>$ The parenting experience has its entrepreneurial benefits: When it comes to balancing work with life and parenting, people tend to think of the challenges. . Most women who are mothers have become adept at multi-tasking many aspects of their lives - often out of necessity rather than any desire to be a multi-tasking wizard. This ability to multi-task is also important for the entrepreneur, who often finds herself wearing many different hats all at the same time.

$>$ Women are better at collaboration: Collaboration can be an important factor when it comes to being a successful entrepreneur. Even big Fortune 500 companies engage in collaboration with other companies, and for the entrepreneur, the ability to collaborate - that is, form relationships and partnerships with other businesses or entrepreneurs - can have a significant impact. Research has found that women prefer collaboration, compared to men, who tend to distrust their colleagues. As an entrepreneur, opportunities to collaborate often arise.

$>$ Women entrepreneurs have the ability to create a women-friendly corporate culture: We've all heard it before: in many companies, the corporate culture can work against women. But when you own your own company, you have the ability to establish the kind of corporate culture that works best for your lifestyle.

$>$ Women's strength in emotional intelligence can be a competitive advantage: Emotional intelligence is the ability to perceive and understand both our own emotions and the emotions of others, and to use this information to help guide how we think and behave. Basically, emotional intelligence is about the ability to work with our feelings. Women can leverage

\section{Data Analysis}

Table No. 1: Age limit of respondents

\begin{tabular}{|l|l|l|}
\hline Age & No of respondents & Percentage \\
\hline $18-20$ & 0 & 0 \\
\hline $21-30$ & 4 & 13 \\
\hline $31-40$ & 7 & 23 \\
\hline 40 and above & 19 & 64 \\
\hline Total & $\mathbf{3 0}$ & $\mathbf{1 0 0}$ \\
\hline
\end{tabular}

Chart No. 1

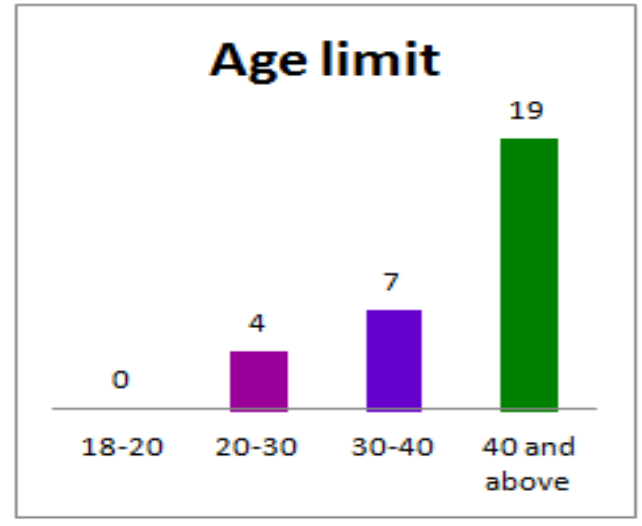


Analysis:

The above table signifies that $13 \%$ of respondents belong to the age group of $21-30$ years where as $23 \%$ of respondents belong to the age group of 31-40 years and remaining 64\% respondents belong to the age group of above 40 years.

Table No. 2: Education qualification of the respondents

\begin{tabular}{|l|l|l|}
\hline Qualification & No. of respondents & Percentage \\
\hline Below SSLC & 13 & 43 \\
\hline PUC & 5 & 17 \\
\hline UG & 10 & 33 \\
\hline PG & 2 & 7 \\
\hline Total & $\mathbf{3 0}$ & $\mathbf{1 0 0}$ \\
\hline
\end{tabular}

Chart No.2

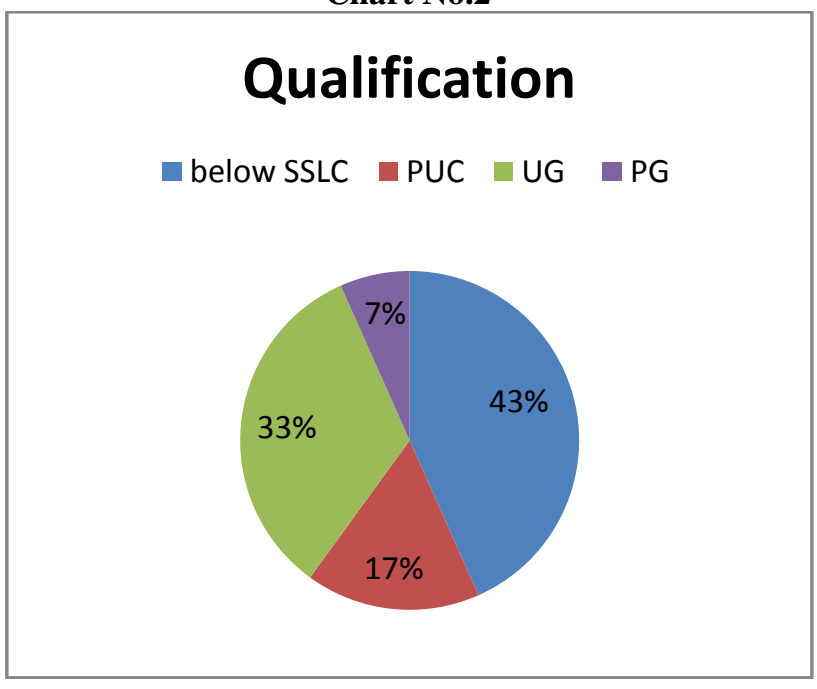

Analysis:

As per the above table out of 30 respondents $43 \%$ of respondents are qualified below SSLC, $17 \%$ of respondents are qualified with PUC, 33\% of respondents are Under Graduates. And 7\% of respondents are Post Graduates.

Table No. 3: Marital status of respondents

\begin{tabular}{|l|l|l|}
\hline Marital status & No. of respondents & Percentage \\
\hline Married & 29 & 97 \\
\hline Unmarried & 1 & 3 \\
\hline Total & $\mathbf{3 0}$ & $\mathbf{1 0 0}$ \\
\hline
\end{tabular}

Chart No. 3

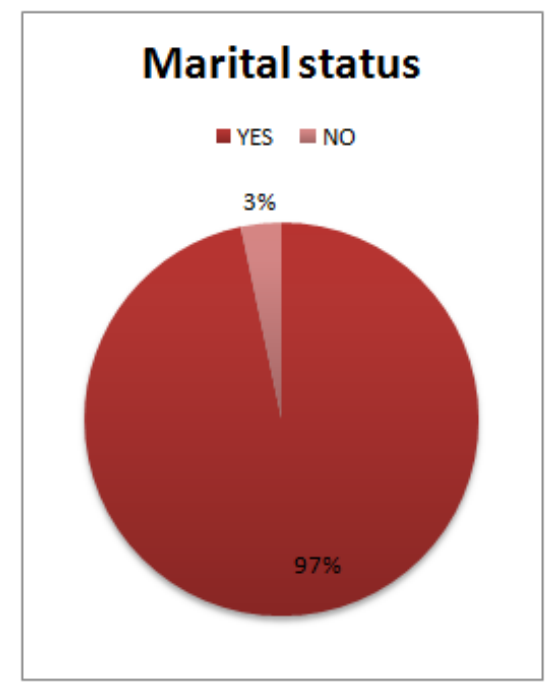


Analysis:

The above table represent that $97 \%$ of respondents are married and rest of $3 \%$ respondents are unmarried.

Table No. 4: Duration of respondents in to the business

\begin{tabular}{|l|l|l|}
\hline Duration of the business & No. of respondents & Percentage \\
\hline $0-15$ & 20 & 67 \\
\hline $16-30$ & 8 & 27 \\
\hline $31-45$ & 0 & 0 \\
\hline 45 and above & 2 & 6 \\
\hline Total & $\mathbf{3 0}$ & $\mathbf{1 0 0}$ \\
\hline
\end{tabular}

Chart No. 4

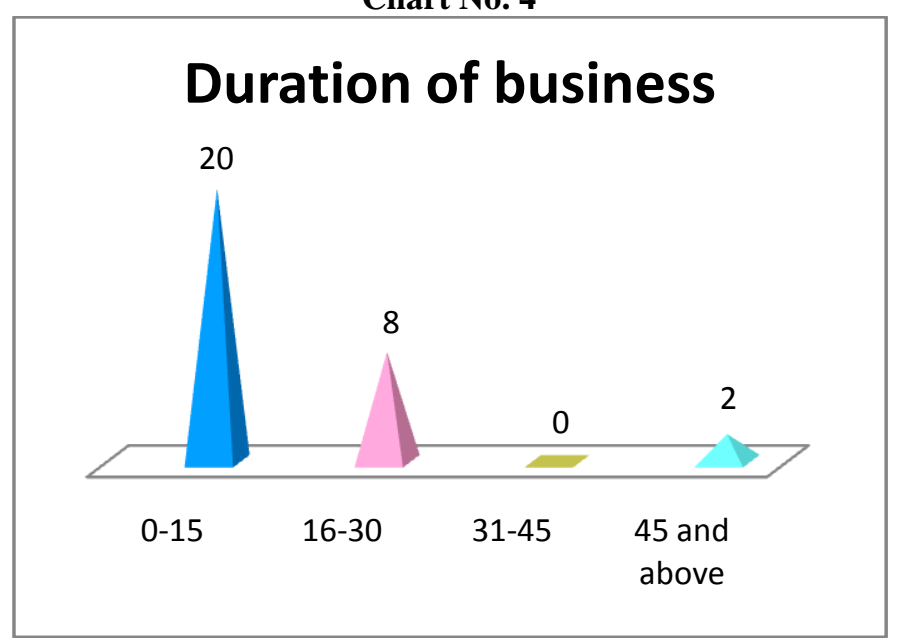

\section{Analysis:}

Above table implies that $67 \%$ of respondents are doing their business since 15 years, $27 \%$ of respondents are doing their business from 16 to 30 years and rest of $6 \%$ respondents are doing their business since from 45 years.

Table No. 5: Showing the reason for start business

\begin{tabular}{|l|l|l|}
\hline Reasons & No. of respondents & Percentage \\
\hline Experience in the field & 8 & 27 \\
\hline Mean of survival & 12 & 40 \\
\hline Structure something new & 10 & 33 \\
\hline Total & $\mathbf{3 0}$ & $\mathbf{1 0 0}$ \\
\hline
\end{tabular}

Chart No. 5

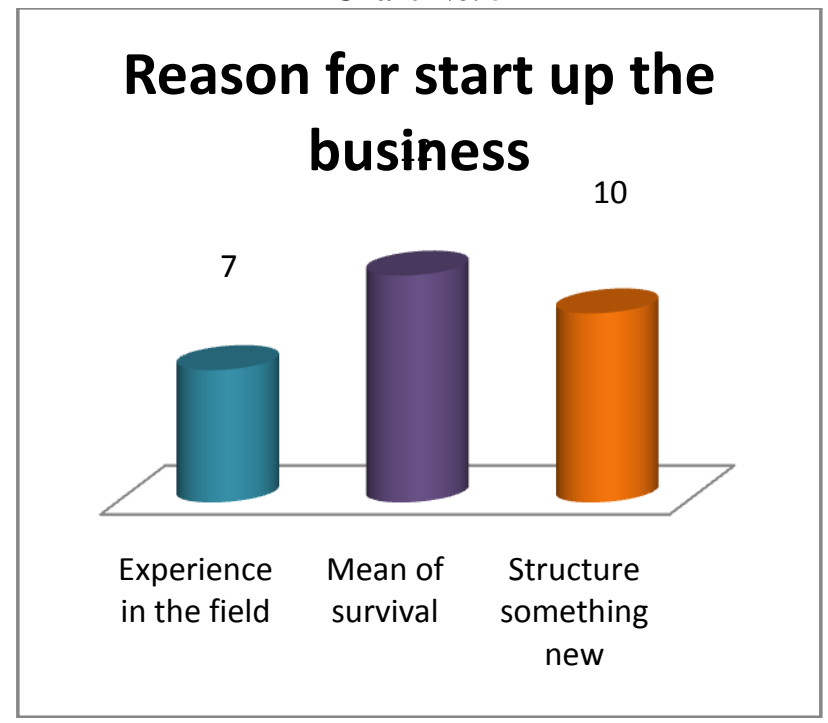


Analysis:

Above chart indicates that $27 \%$ of respondents started their business to get an experience in the field, $40 \%$ of respondents started as a mean of survival and remaining $33 \%$ of respondents started in order to something new.

Table no. 6: Size of the family

\begin{tabular}{|l|l|l|}
\hline Family size & No. of respondents & Percentage \\
\hline Less than 5 & 17 & 57 \\
\hline More than 5 & 13 & 43 \\
\hline Total & $\mathbf{3 0}$ & $\mathbf{1 0 0}$ \\
\hline
\end{tabular}

Chart No. 6

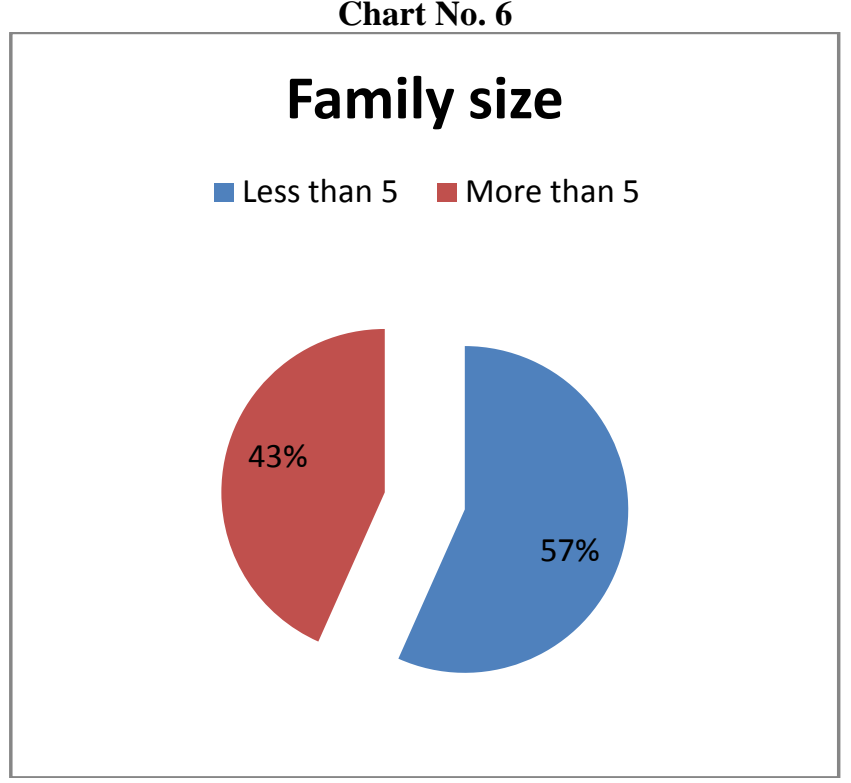

\section{Analysis:}

As per the above table represent that out of 30 respondents $57 \%$ of respondents belong to the family of less than 5 and $43 \%$ of respondents belongs to the family of more than 5 .

Table No. 7:Table showing the place of work

\begin{tabular}{|l|l|l|}
\hline Location of work & No. of respondents & Percentage \\
\hline Work at shop & 13 & 44 \\
\hline Work at home & 7 & 23 \\
\hline Others & 10 & 33 \\
\hline Total & $\mathbf{3 0}$ & $\mathbf{1 0 0}$ \\
\hline
\end{tabular}

Chart No. 7

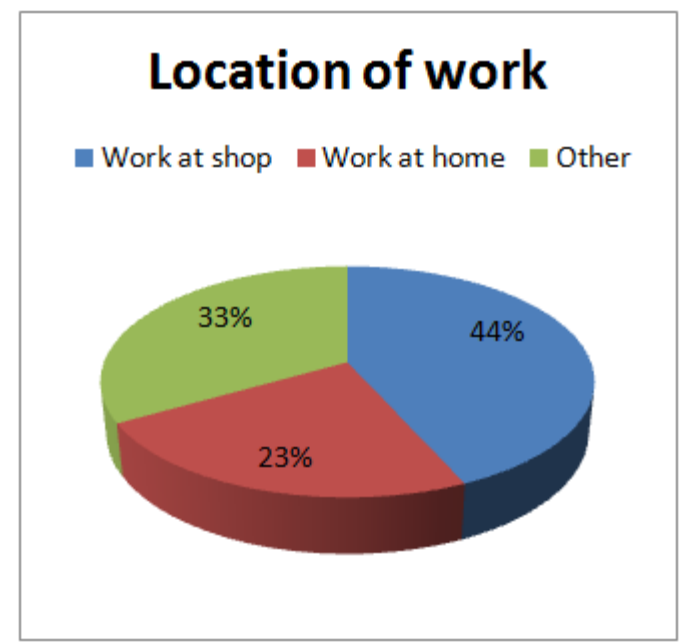


Analysis:

According to graph $44 \%$ of respondents work at shop where as $23 \%$ of respondents work at home and $33 \%$ of respondents works in fair or fest etc.

Table No. 8: Support from the family

\begin{tabular}{|l|l|l|}
\hline & NO. of respondents & Percentage \\
\hline Yes & 27 & 90 \\
\hline No & 3 & 10 \\
\hline Total & $\mathbf{3 0}$ & $\mathbf{1 0 0}$ \\
\hline
\end{tabular}

Chart No. 8

\section{Support from family}

$\square 1 \square 2$

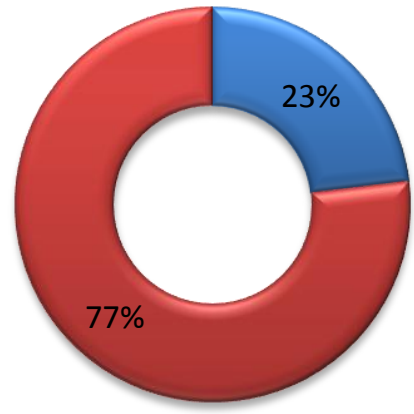

Analysis:

As per the above graph $23 \%$ of respondents have support from their family and remaining $77 \%$ of respondents do not have support from their family.

Table No. 9: The subsidies or financial assistance from the government

\begin{tabular}{|l|l|l|}
\hline & No. of respondents & Percentage \\
\hline Yes & 12 & 40 \\
\hline No & 18 & 60 \\
\hline Total & $\mathbf{3 0}$ & $\mathbf{1 0 0}$ \\
\hline
\end{tabular}

Chart No. 9

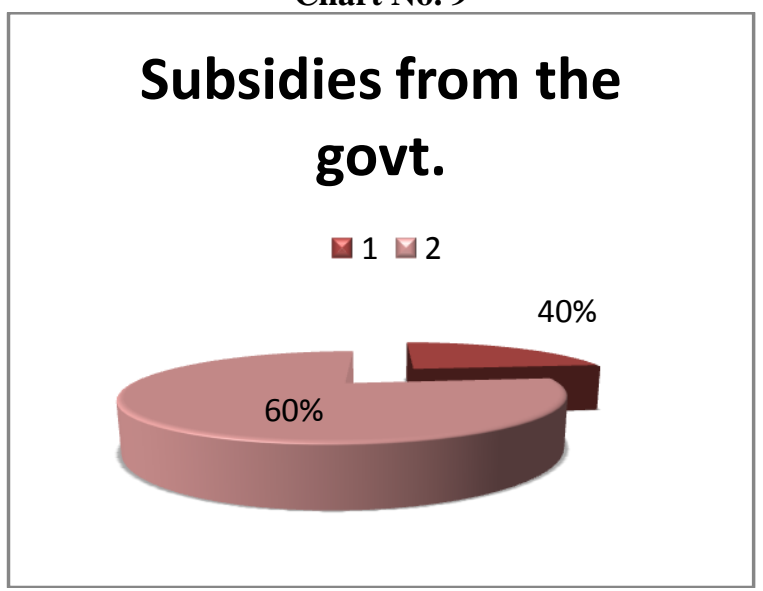

Analysis:

The above table show up out of 30 respondents $40 \%$ of respondents are getting the subsidies from the government and rest of $60 \%$ of respondents not getting subsidies from the government. 
Table No. 10: The member of SHG

\begin{tabular}{|l|l|l|}
\hline & No. of respondents & Percentage \\
\hline Yes & 16 & 53 \\
\hline No & 14 & 47 \\
\hline Total & $\mathbf{3 0}$ & $\mathbf{1 0 0}$ \\
\hline
\end{tabular}

Chart No. 10

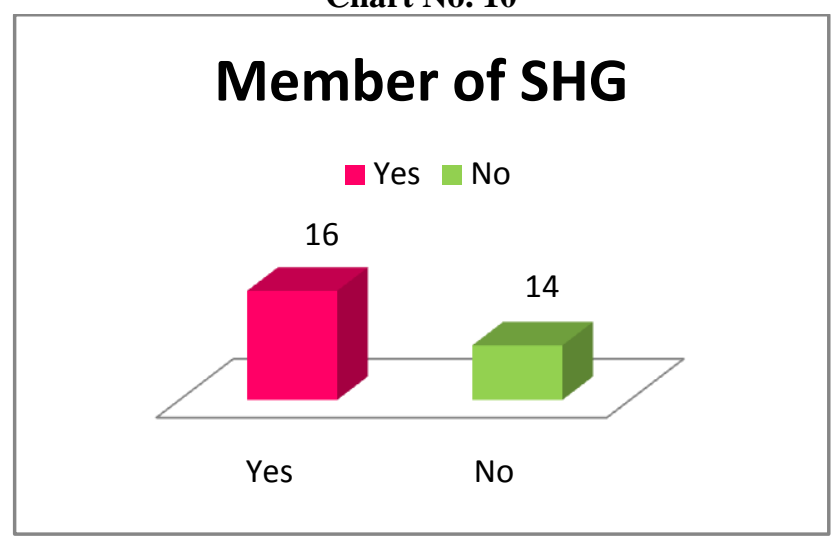

\section{Analysis:}

The above table symbolizes that to $53 \%$ of respondents are member of SHG and remaining $47 \%$ of respondents are not a member of SHG

Table No .11: The promotion strategy of business

\begin{tabular}{|l|l|l|}
\hline & No. of respondents & Percentage \\
\hline Yes & 8 & 27 \\
\hline No & 22 & 73 \\
\hline Total & $\mathbf{3 0}$ & $\mathbf{1 0 0}$ \\
\hline
\end{tabular}

Chart No. 11

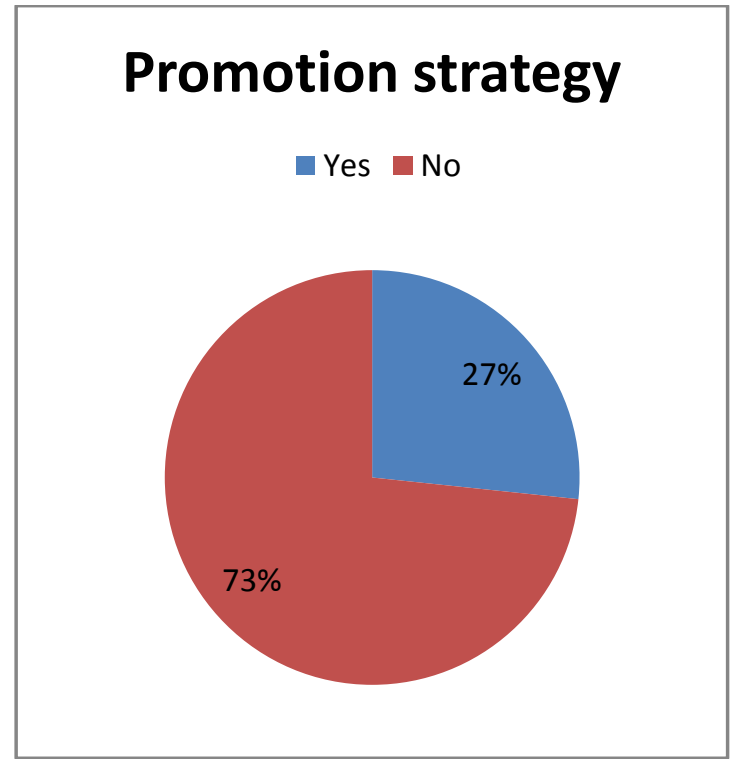

\section{Analysis:}

From the above graph it is clear that $27 \%$ of respondents use promotion strategy like advertisement in their business and $73 \%$ of respondents do not use any promotion strategy for their business.

Table No. 12 The comfort ability with business

\begin{tabular}{|l|l|l|}
\hline & No. of respondents & Percentage \\
\hline Yes & 29 & 97 \\
\hline No & 1 & 3 \\
\hline Total & $\mathbf{3 0}$ & $\mathbf{1 0 0}$ \\
\hline
\end{tabular}


Chart No. 12

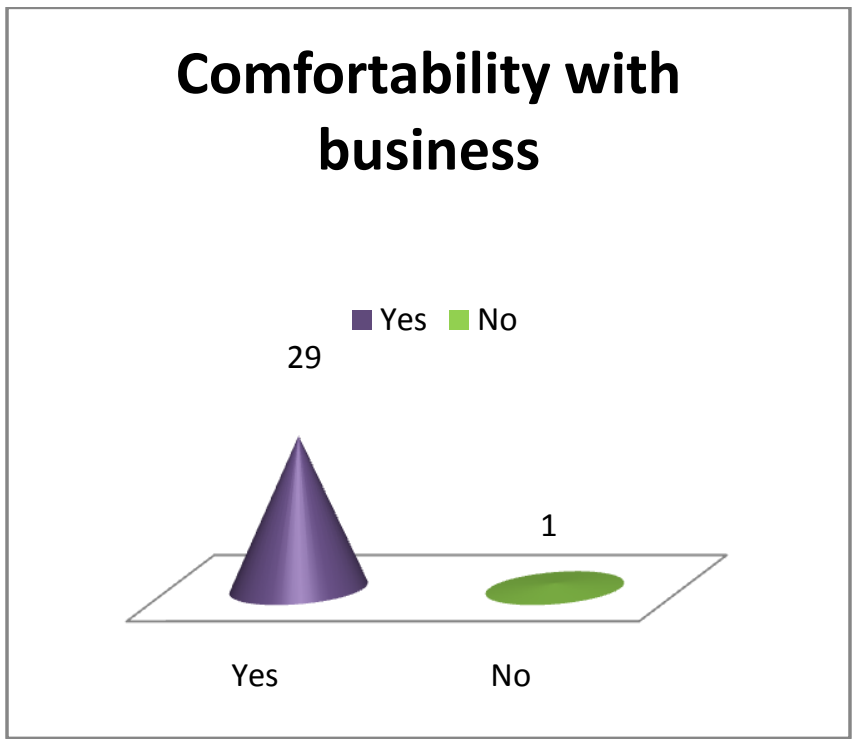

Analysis:

From the table indicates that $97 \%$ of respondents are comfortable with their business and $3 \%$ of respondents are not comfortable with their business.

Table No. 13: Number of regular customer

\begin{tabular}{|l|l|l|}
\hline & No. of respondents & Percentage \\
\hline Yes & 28 & 93 \\
\hline No & 2 & 7 \\
\hline Total & $\mathbf{3 0}$ & $\mathbf{1 0 0}$ \\
\hline
\end{tabular}

Chart No. 13

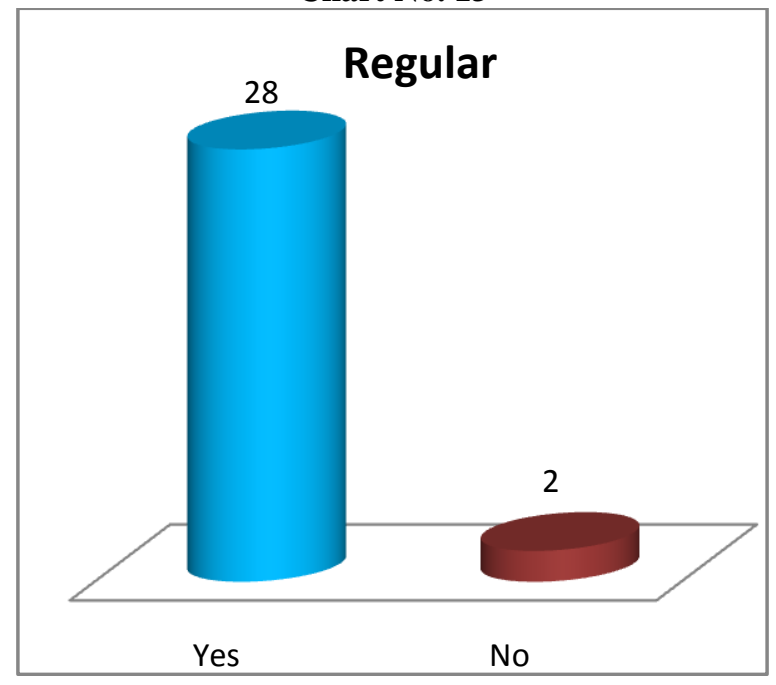

Analysis:

Above table implies that $93 \%$ of respondents have regular customer and remaining $7 \%$ of respondents do not have any regular customer.

Table No. 14: Usage of strategies to attract the customer

\begin{tabular}{|l|l|l|}
\hline & No of respondents & Percentage \\
\hline Yes & 25 & 83 \\
\hline No & 5 & 17 \\
\hline Total & $\mathbf{3 0}$ & $\mathbf{1 0 0}$ \\
\hline
\end{tabular}


Chart No. 14

\section{Usage of strategy}

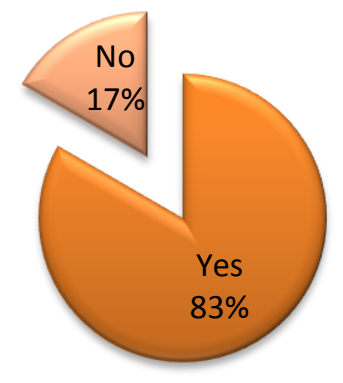

Analysis:

The above table it is clear that out of 30 respondents $83 \%$ of respondents use strategies to attract the customer and $17 \%$ of respondents do not use any strategies.

Table No. 15: Success with the business

\begin{tabular}{|l|l|l|}
\hline & No. of respondents & Percentage \\
\hline Yes & 29 & 97 \\
\hline No & 1 & 3 \\
\hline Total & $\mathbf{3 0}$ & $\mathbf{1 0 0}$ \\
\hline
\end{tabular}

Chart No. 15

\section{Success of business}

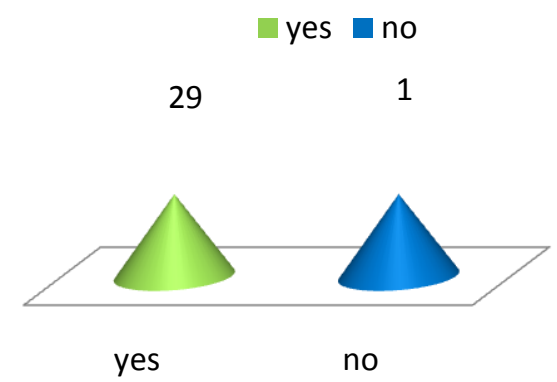

\section{Analysis:}

Above table shows that $97 \%$ respondents are success with their business and $3 \%$ of respondents are not success with their business.

\section{HYPOTHESIS TESTING}

$\mathbf{H} \square$ : There is no significantrelationship between reason to start the business and Educational Qualification

$\mathbf{H}_{1}$ : there is significant relationship between reason to start the business and Educational Qualification

\begin{tabular}{|c|c|c|c|c|c|}
\hline & \multicolumn{5}{|c|}{ Educational Qualification } \\
\hline Reason & Below SSLC & PUC & $\mathbf{U G}$ & PG & Total \\
\hline Experience & 5 & 1 & 2 & $\mathbf{0}$ & 8 \\
\hline Survival & 6 & 3 & 2 & 1 & 12 \\
\hline Structure something new & 2 & 1 & 6 & 1 & 10 \\
\hline Total & 13 & 5 & 10 & 2 & 30 \\
\hline
\end{tabular}




\begin{tabular}{|c|c|c|c|c|}
\hline $\mathrm{O}$ & $\mathrm{E}$ & O-E & $(\mathrm{O}-\mathrm{E})^{2}$ & $(\mathrm{O}-\mathrm{E})^{2} / \mathrm{E}$ \\
\hline 5 & 3.47 & 1.53 & 2.3409 & 0.6746 \\
\hline 1 & 1.33 & -0.33 & 0.1089 & 0.08188 \\
\hline 2 & 2.67 & -0.67 & 0.4489 & 0.16813 \\
\hline 0 & 0.53 & -0.53 & 0.2809 & 0.53 \\
\hline 6 & 5.2 & 0.8 & 0.64 & 0.12308 \\
\hline 3 & 2 & 1 & 1 & 0.50 \\
\hline 2 & 4 & -2 & 4 & 1 \\
\hline 1 & 0.8 & 0.2 & 0.04 & 0.05 \\
\hline 2 & 4.33 & -2.33 & 5.4289 & 1.25379 \\
\hline 1 & 1.67 & -0.67 & 0.4489 & 0.26880 \\
\hline 6 & 3.33 & 2.67 & 7.1289 & 2.1408 \\
\hline 1 & 0.67 & 0.33 & 0.1089 & 0.16254 \\
\hline & \multicolumn{3}{|c|}{$\mathbf{X}^{2}$} & 6.95362 \\
\hline
\end{tabular}

$X$-squared $=6.95362 \mathrm{df}=6$

\section{Interpretation:}

Tabulated value of chi-square at $5 \%$ level of significance and 6 degrees of freedom is 18.548 and calculated value is 6.95362 . So we can conclude that there is no significant relationship between reason to start the business and educational qualification.

\section{$\mathbf{H} \square:$ Size of the family and Support from family are independent} $\mathrm{H}_{1}$ : Size of the family and Support from family are dependent

\begin{tabular}{|l|c|c|c|}
\hline & \multicolumn{3}{|c|}{ Support from the family } \\
\hline Size of the family & Positive support & No support & Total \\
\hline Less than 5 & 16 & 1 & 17 \\
\hline More than 5 & 11 & 2 & 13 \\
\hline Total & 27 & 3 & 30 \\
\hline
\end{tabular}

\begin{tabular}{|c|c|c|c|c|}
\hline $\mathbf{O}$ & $\mathbf{E}$ & O-E & $(\mathrm{O}-\mathrm{E})^{2}$ & $(\mathrm{O}-\mathrm{E})^{2} / \mathrm{E}$ \\
\hline 16 & 15.3 & 0.7 & 0.49 & 0.03203 \\
\hline 1 & 1.7 & -0.7 & 0.49 & 0.28824 \\
\hline 11 & 11.7 & -0.7 & 0.49 & \begin{tabular}{|l|l|}
0.04188 \\
\end{tabular} \\
\hline 2 & 1.3 & $\begin{array}{ll}0.7 \\
\end{array}$ & 0.49 & \begin{tabular}{|l|}
$\mathbf{0 . 3 7 6 9 2}$ \\
\end{tabular} \\
\hline & \multicolumn{3}{|c|}{ 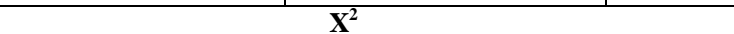 } & \begin{tabular}{|l}
$\mathbf{0 . 7 3 9 0 7}$ \\
\end{tabular} \\
\hline
\end{tabular}

$\mathrm{X}$-squared $=0.73907 \mathrm{df}=1$

\section{Interpretation:}

Tabulated value of chi-square at $5 \%$ level of significance and 1 degrees of freedom is 7.879 and calculated value is 0.73907 . So we can conclude that size of the family and support from the family are independent.

\section{Findings}

1. Majority of the women entrepreneurs are minimum qualified.

2. At a stretch the business has been started 15 years back and their skill continuing the same.

3. The main purpose of all the women entrepreneurs is to become financially independent and look after their family and also some has done so for fulfilling their passion.

4. Majority of women entrepreneurs are being supported by their family as the main reason behind starting the business is to increase the standard of living of the family.

5. Initially they found it difficult investment hence; they have availed loan facilities and also pledged their asset.

6. Some of the women entrepreneurs have got support by the government whereas some get indirect support by being a member of SHG.

7. As they are women entrepreneurs the main strategy used by them is word of mouth and customers trust them and by their products regularly ensuring them a regular source of income hence, the business started by them does not fail because of the way and strategies adopted by them.

\section{Suggestions}

1. By findings it can suggested that more government support should be given to women entrepreneurs.

2. As majority of women lack technical skill so, they must adopt technical skill in their business.

3. They should use proper marketing strategies such as advertising, door to door delivery, Brand building, to promote the product. 
4. Government should provide the information about the schemes related to women empowerment.

5. Encourage involvement of private participation in women empowerment Programmes

\section{Conclusion}

Women entrepreneur is a person who accepts challenging role to meet her personal need and become economically independent. A woman's entrepreneurship can make a strong contribution to the economic wellbeing of the family and communities, poverty reduction. The governments across the world, as well as various developmental organizations, are actively undertaking the promotion of female entrepreneurs through various schemes, incentives and promotional measures. The number of self-employed women has steadily increased over the past three decades, putting them at an approximate thirty-three percent increase. Many female-owned businesses continue to be home-based operations. Thus they are playing a vital role in the balanced development of the economy. It is said that if you educate a women you are educating a family. When the women become independent she has a voice not only in the family but in the whole society thus it results reduction of woman harassment and improves gender equality thus resulting in a welfare state.

\footnotetext{
[1]. www.timesofindia.com

[2]. www.businessline.com

[3]. www.economictimes.com

[4]. www.scribd.com
}

\section{References}

